\title{
The transformation of the global palm oil cluster: dynamics of cluster competition between Africa and Southeast Asia (c.1900-1970)*
}

\author{
Valeria Giacomin \\ Harvard Business School, Soldiers Field, Boston, MA 02163, USA \\ E-mail: vgiacomin@hbs.edu
}

\begin{abstract}
This article explains the rise of palm oil as a global commodity during the twentieth century as the result of cooperation and competition between two different clusters in former colonial territories. The connection between these two locations was mediated by Western companies, colonial officials, scientists, and businessmen. Eventually, the Southeast Asian cluster, organized on estate lines inherited from rubber, outcompeted the old one in Africa, mostly based on the farming of semi-wild trees. The article investigates the activities of scientists and businessmen exchanging information, knowledge, and practice between Africa and Asia for almost a century. It shows that cooperation among communities of practice helped to advance palm oil knowledge, but also created increased rivalry between the two locations. Thanks to the mobility of experts, and to knowledge exchange in colonial and early postcolonial times, multinationals were able to replicate clusters across locations with similar climate, taking advantage of a business environment more conducive to foreign investment.
\end{abstract}

Keywords Africa, cluster competition, communities of experts, palm oil, Southeast Asia

I would like to thank the staff of the archives I consulted in writing this article: the British National Archives in Kew, the London Metropolitan Archives, the Guthrie Collection at the SOAS Archives, and the Barlow Collection at Cambridge University Library. A special mention goes to Henry Barlow for kindly granting access to all the records in his family's collection. I am very grateful to the Unilever Archives team, and especially to Jessica Handy, for allowing access to the archives at the company's premises in Port Sunlight (Liverpool). Finally, I would like to thank Christina Lubinski, Geoffrey Jones, Andrea Colli, Nick White, Pavida Pananond, David Kirsch, Joost Dankers, Chris Kobrak, Keetie Sluyterman, Jan Luiten van Zanden, and the two anonymous referees for their comments on the drafts of this article. 
THE GLOBAL PALM OIL CLUSTER, C. $1900-1970 \mid 375$

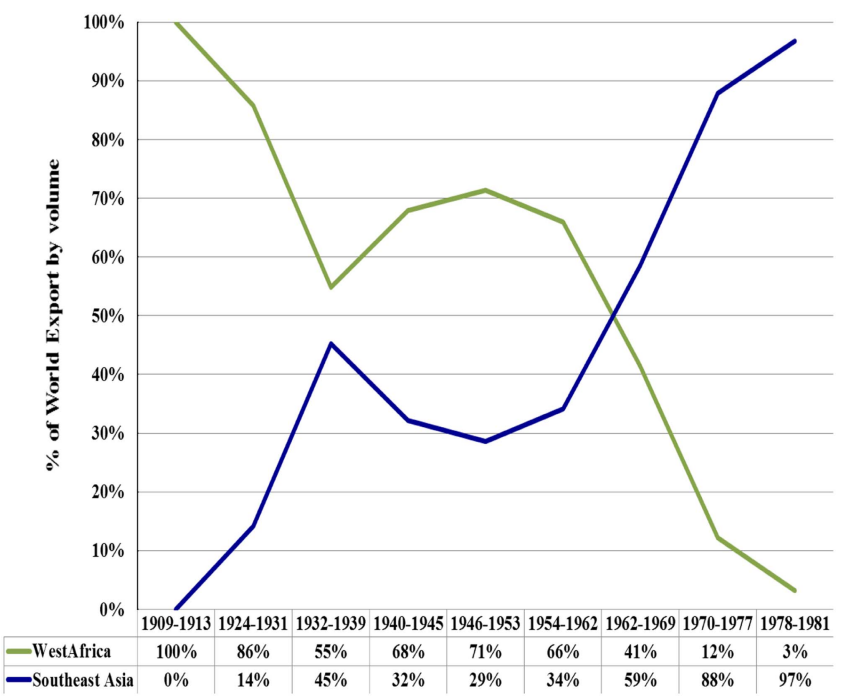

Figure 1. Shares of palm oil world export by cluster (Southeast Asia and West Africa).

Source: data from: P. B. Tinker and R. H. V. Corley, The oil palm, Hoboken, NJ: WileyBlackwell, 2016.

The transfer of agricultural crops across the tropics, from politically unstable locations to colonially controlled ones, has been a common strategy for foreign traders, to counter the risk attached to investing in volatile, underdeveloped territories. ${ }^{1}$ The introduction to Southeast Asia of the rubber tree and the oil palm, from the forests of the Amazon and West Africa respectively, supported the rise of the automotive industry in the early twentieth century, and of oil-based products in the interwar period. When demand for these commodities boomed, the Southeast Asian location outcompeted both locations of origin, thanks to a more efficient organization of production and a favourable ecological environment. Unlike the Amazon, whose rubber exports quickly lost competitiveness, in the case of palm oil the two cluster locations coexisted as global suppliers for more than fifty years (see Figure 1). The dynamics of knowledge exchange and competition between these two agricultural poles explain the rise of palm oil as global commodity. From the 1970s, palm oil surfaced as one of the major vegetable oils in terms of volume, and today is primarily produced in Malaysia and Indonesia (see Figure 2).

This article is situated at the intersection of global history, economic geography, and international business studies. It draws from contributions on knowledge formation and transmission in cluster studies, as well as from the literature on communities of experts (or practice), to show how the global palm oil industry developed through competition between similar clusters in colonial territories. ${ }^{2}$ The bulk of studies on industrial

1 Alfred Crosby, Ecological imperialism: the biological expansion of Europe, 900-1900, Cambridge: Cambridge University Press, 2004.

2 Alfred Marshall, Principles of economics, 8th edn, London: Macmillan, 1920; Michael E. Porter, 'Location, competition, and economic development: local clusters in a global economy', Economic Development Quarterly, 14, 1, 2000, pp. 15-34; Michael E. Porter and Christian Ketels, 'Clusters and industrial districts: common roots, different perspectives', in Giacomo Becattini, ed., Handbook of industrial districts, Cheltenham: Edward Elgar, 2009, pp. 172-83. 


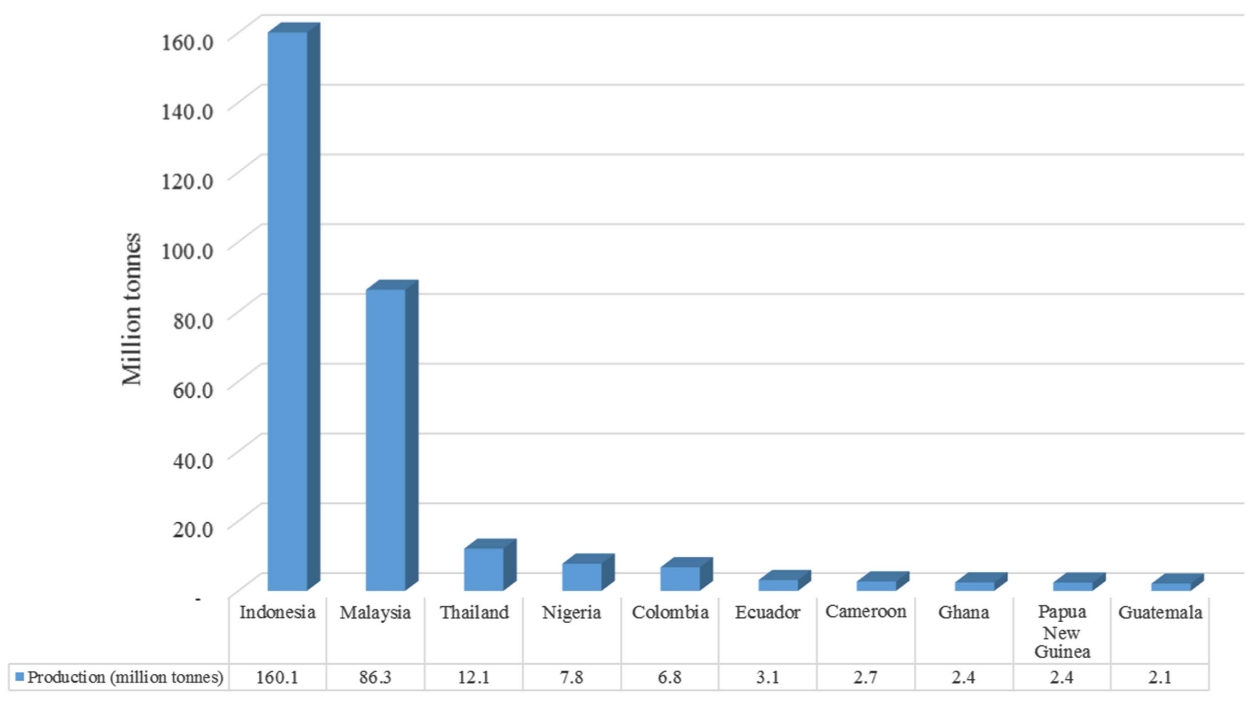

Figure 2. Ranking of palm oil-producing countries in 2016 (million tonnes).

Source: FAO Statistics, http://www.fao.org/faostat/en/\#rankings/countries_by_commodity (consulted 16 February 2018).

agglomeration conceive of clusters as self-contained production centres, characterized by a high degree of specialization and location-specific institutions. ${ }^{3}$ Industrial concentration facilitates knowledge transfer and positive externalities, which Marshall famously defined as 'industrial atmosphere'. ${ }^{4}$ However, especially when directed to export, clusters are also highly connected via a mobile community of experts, notably businessmen, scientists, and, in some cases, colonial officials.

The fact that palm oil is a fairly standardized product and that the trees grow exclusively in an equatorial climate, approximately 14 degrees of latitude around the equator, enables a comparison of the performance of its major suppliers, Africa and Southeast Asia, both organized in clusters (see Table 1 for a list of cluster institutions in the two locations). In light of this, the common phenomenon of the transfer of agricultural crops can be interpreted as clusters being replicated or 'moving' from one location to another, more suitable area, and competing against each other. While the existing historiography on palm oil concentrates on local dynamics, this study shows the evolution of the industry as the result of a broader interaction within different colonial and postcolonial environments.

In this article, the dynamics of cluster competition are interpreted as the result of the relationship and knowledge exchange between communities of experts and investors in these different locations over time. The analysis is based on five major public and private archives in

3 Danny MacKinnon, Andrew Cumbers, and Keith Chapman, 'Learning, innovation and regional development: a critical appraisal of recent debates', Progress in Human Geography, 26, 3, 2002, pp. 293-311; Jonathan Zeitlin, 'Industrial districts and regional clusters', in Geoffrey Jones and Jonathan Zeitlin, eds., The Oxford handbook of business history, Oxford: Oxford University Press, 2008, pp. 219-43; Anders Malmberg and Peter Maskell, 'The elusive concept of localization economies: towards a knowledge-based theory of spatial clustering', Environment and Planning A, 34, 3, 2002, pp. 429-49.

4 Alfred Marshall, Industry and trade: a study of industrial technique and business organization, London: Macmillan, 1923. 
Table 1. Major cluster players in Africa and Southeast Asia during the period under study

\begin{tabular}{|c|c|c|c|c|}
\hline Function & Institutions & $\begin{array}{l}\text { Year } \\
\text { founded }\end{array}$ & Headquarters & Members/promoters \\
\hline \multirow[t]{10}{*}{ Producers } & Sumatran Pool & $\begin{array}{r}1920 s- \\
1940 s\end{array}$ & $\mathrm{n} / \mathrm{a}$ & $\mathrm{n} / \mathrm{a}$ \\
\hline & Malaysian Pool & $\begin{array}{l}\text { during } \\
\text { the } \\
1930 \text { s }\end{array}$ & London & $\begin{array}{l}\text { Guthrie; Harrison and Crosfield (H\&C); } \\
\text { Barlow; United Plantations (UP); Société } \\
\text { Financière des Caoutchoucs (Socfin) }\end{array}$ \\
\hline & Unilever & $\begin{array}{l}\text { enters } \\
\text { Malaya } \\
\text { in } 1947\end{array}$ & Port Sunlight & $\begin{array}{l}\text { Plantation Estate Group (including all } \\
\text { Unilever's plantations) }\end{array}$ \\
\hline & $\begin{array}{l}\text { Colonial Development } \\
\text { Corporation (CDC) }\end{array}$ & 1948 & London & British colonial government \\
\hline & $\begin{array}{l}\text { Nigerian Palm Oil Marketing } \\
\text { Board }\end{array}$ & 1949 & Nigeria & British colonial government \\
\hline & $\begin{array}{l}\text { Malaysian Palm Oil Pool } \\
\text { (MPOP) }\end{array}$ & 1952 & $\begin{array}{l}\text { Kuala } \\
\text { Lumpur }\end{array}$ & Guthrie; H\&C; Barlow; UP; Socfin \\
\hline & Joint Selling Committee (JSC) & 1952 & London & $\begin{array}{l}\text { MPOP members controlling bulking facilities } \\
\text { (Guthrie; H\&C; UP; Socfin) }\end{array}$ \\
\hline & $\begin{array}{l}\text { Federal Land Development } \\
\text { Authority (FELDA) }\end{array}$ & 1956 & $\begin{array}{l}\text { Kuala } \\
\text { Lumpur }\end{array}$ & Malaysian smallholders; Malaysian state \\
\hline & $\begin{array}{l}\text { Oil Palm Growers' Council } \\
\text { (OPGC) }\end{array}$ & 1968 & $\begin{array}{l}\text { Kuala } \\
\text { Lumpur }\end{array}$ & big estates; planters; FELDA \\
\hline & $\begin{array}{l}\text { Malaysian Palm Oil Company } \\
\text { (MPOC) }\end{array}$ & 1969 & $\begin{array}{l}\text { Kuala } \\
\text { Lumpur }\end{array}$ & FELDA and MPOP \\
\hline \multirow[t]{18}{*}{ Research } & $\begin{array}{l}\text { Agricultural Department of } \\
\text { Malaya }\end{array}$ & & Serdang & British colonial government \\
\hline & $\begin{array}{l}\text { Algemeene Vereeniging van } \\
\text { Rubberplanters ter Oostkust } \\
\text { van Sumatra (AVROS) station }\end{array}$ & & Medan & $\begin{array}{l}\text { Association of estate growers in East } \\
\text { Sumatra }\end{array}$ \\
\hline & Chemara Estates & & Malaya & Guthrie \\
\hline & Dusun Durian Estate & & Malaya & $\mathrm{H} \& \mathrm{C}$ \\
\hline & Elmina Estates & & Malaya & Barlows \\
\hline & $\begin{array}{l}\text { Gold Coast Agricultural } \\
\text { Department }\end{array}$ & & Accra & British colonial government \\
\hline & $\begin{array}{l}\text { Huileries du Congo Belge (HCB) } \\
\text { research }\end{array}$ & & $\begin{array}{l}\text { Belgian } \\
\text { Congo }\end{array}$ & Unilever \\
\hline & $\begin{array}{l}\text { Incorporated Society of Planters } \\
\text { (ISP) }\end{array}$ & 1919 & $\begin{array}{l}\text { Kuala } \\
\text { Lumpur }\end{array}$ & $\begin{array}{l}\text { Dissemination activities on behalf of planters } \\
\text { in Malaya }\end{array}$ \\
\hline & $\begin{array}{l}\text { Institut National pour l'Étude } \\
\text { Agronomique du Congo Belge } \\
\text { (INEAC) }\end{array}$ & & $\begin{array}{l}\text { Belgian } \\
\text { Congo }\end{array}$ & Belgian colonial government \\
\hline & $\begin{array}{l}\text { Malaysian Agricultural Research } \\
\text { and Development Institute } \\
\text { (MARDI) }\end{array}$ & 1969 & $\begin{array}{l}\text { Kuala } \\
\text { Lumpur }\end{array}$ & Malaysian Ministry of Agriculture \\
\hline & Nigeria Agricultural Department & & Ibadan & British colonial government \\
\hline & Oil Palm Genetic Consortium & $\begin{array}{r}1963- \\
1973\end{array}$ & $\begin{array}{l}\text { Kuala } \\
\text { Lumpur }\end{array}$ & Dunlop; Guthrie; H\&C; Unilever \\
\hline & $\begin{array}{l}\text { Oil Palm Research Station } \\
\text { (WAIPOR) }\end{array}$ & 1938 & Benin & British colonial government \\
\hline & Oil Palm Subcommittee (OPS) & $\mathrm{n} / \mathrm{a}$ & London & British government \\
\hline & Royal Botanic Gardens, Kew & & London & British government \\
\hline & $\begin{array}{l}\text { Rubber Growers’ Association } \\
\text { (RGA) }\end{array}$ & $\begin{array}{l}\text { enters } \\
\text { palm oil } \\
\text { after } \\
1965\end{array}$ & London & $\begin{array}{l}\text { agency houses and large plantation } \\
\text { companies }\end{array}$ \\
\hline & Tennamaram Estates & & Malaya & UP \\
\hline & $\begin{array}{l}\text { Tropical Production Institute } \\
\text { (TPI) }\end{array}$ & 1955 & London & British government \\
\hline
\end{tabular}

Sources: Compilation of archival material (TNA, LMA, BC, UL) and secondary sources (Tate, $R G A$ history; Martin, UP saga; White, British business). 
the UK, as well as on fieldwork material collected in Singapore and Malaysia in 2014. Part of the material concerns the primary cluster members involved in palm oil production the time: the Harrison and Crosfield papers in the London Metropolitan Archives; the Guthrie papers in the library of SOAS, University of London; the Barlow Collection in Cambridge University Library; and the Unilever archives in Port Sunlight. In addition, public records were consulted in the Rubber Growers' Association (RGA) and Colonial Office collections held at The National Archives of the United Kingdom, and in the London Metropolitan Archives.

The next section reviews the literature on communities of practice and knowledge creation in relation to cluster competition, and illustrates how this research contributes to the existing scholarship on the palm oil industry, clusters, and communities of experts. Sections three to six present the historical analysis in chronological order: the third section compares palm oil production in the two locations, and sets the scene in the colonial period; the fourth section studies the exchange of knowledge among the community of oil palm experts in the interwar period, when the Southeast Asian cluster emerged to threaten African leadership in palm oil exports; the fifth section describes the developments in the aftermath of the Second World War; and the sixth section examines the rise of Malaysia as the dominant palm oil exporter during the 1950s and 1960s. The last section summarizes the findings and concludes.

\section{Communities of experts across competing clusters}

The phenomenon of clustering, namely the sectorial and spatial concentration of specialized firms, is an established line of research across the social sciences. ${ }^{5}$ Departing from Marshall's seminal work on industrial agglomerations (or districts), Porter coined the term 'clusters' to define a 'geographically proximate group of interconnected companies and associated institutions on a particular field linked by commonalities and externalities'. ${ }^{6}$ Specifically, clusters are characterized by geographical focus (namely country, region, or climatically homogeneous area), product specialization, and supportive business environment (physical infrastructure and institutions). ${ }^{7}$ In Porter's view, clusters help regions and nations to foster economic growth via higher productivity, and to improve their export competitiveness. ${ }^{8}$ The idea that industrial concentration and product specialization drive local development has been studied in different fields. ${ }^{9}$

However, because of their emphasis on local dynamics, studies on clusters, even in historical perspective, have been repeatedly accused of underplaying the role of locations' external links, and of being excessively 'self-contained' in looking at sources of economic success in these locations. ${ }^{10}$ For instance, most literature on the history of palm oil tends to concentrate on how production clustered either in Asia or in Africa, instead of providing an overarching

$5 \quad$ Hubert Schmitz and Khalid Nadvi, 'Clustering and industrialization: introduction', World Development, 27, 9, 1999, pp. 1503-14.

6 Marshall, Principles; Porter, 'Location', p. 16.

7 Michael E. Porter, 'Clusters and the new economics of competition', Harvard Business Review, 76, 6, 1998, pp. 77-90.

8 Michael E. Porter, The competitive advantage of nations, Basingstoke: Palgrave Macmillan, 1998.

9 Sara C. S. Cruz and Aurora A. C. Teixeira, 'The evolution of the cluster literature: shedding light on the regional studies-regional science debate', Regional Studies, 44, 9, 2010, pp. 1263-88.

10 MacKinnon, Cumbers and Chapman, 'Learning'; Zeitlin, 'Industrial districts'; John Humphrey and Hubert Schmitz, 'Governance and upgrading: linking industrial cluster and global value chain research', Institute of Development Studies working paper 120, 2000. 
perspective on its global development. ${ }^{11}$ In contrast, this article argues that studying clusters, specifically the ones centring on commodities produced in colonial territories, helps to understand how the global economy has been formed. ${ }^{12}$ Global capitalism expanded geographically according to the logics of imperialism, with international trade flows connecting industrialized imperial powers to a system of primarily extractive clustered activities in colonial territories, providing natural resources and agricultural commodities. This system was institutionalized through the creation of stable channels of exchange, also theorized as global commodity or value chains. According to this scholarship, 'lead firms', often major multinationals, coordinated resources and power relations along the nodes of the chains. ${ }^{13} \mathrm{~A}$ vast literature in the field of globalization and development studies, rooted in Wallerstein's world systems theory, has argued that developing countries could grow by joining these chains via specialized clusters, often the product of foreign investment. ${ }^{14}$

Similarly, research in business history and global history abundantly documented the relevance of dynamics of co-location and knowledge exchange across the world, as the result of the activity of specific actors and organization within transnational networks. ${ }^{15}$ Charles Jones introduced the notion of a 'cosmopolitan bourgeoisie', ethnically heterogeneous networks of families and trading communities concentrated in a wide net of hubs (mostly port locations) for global trade, to document the social structures behind the genesis and expansion of the global economy, which underlay the British empire during the nineteenth century. ${ }^{16}$

11 Basil N. Ukegbu, 'Production in the Nigerian oil palm industry, 1900-1954', PhD thesis, University of London, 1974; Eno J. Usoro, The Nigerian oil palm industry (government policy and export production, 19061965), Ibadan: Ibadan University Press, 1974; Susan M. Martin, Palm oil and protest: an economic history of the Ngwa region, south-eastern Nigeria, 1800-1980, New York: Cambridge University Press, 1988; D. J. M. Tate, The RGA history of the plantation industry in the Malay Peninsula, Kuala Lumpur: Oxford University Press, 1996; Susan M. Martin, The UP saga, Copenhagen: Nordic Institute of Asian Studies, 2003.

12 Sandip Hazareesingh and Jonathan Curry-Machado, 'Editorial: commodities, empires, and global history', Journal of Global History, 4, 1, 2009, pp. 1-5.

13 Gary Gereffi and Raphael Kaplinsky, The value of value chains: spreading the gains from globalization, Brighton: Institute of Development Studies at the University of Sussex, 2001; Gary Gereffi and Miguel Korzeniewicz, Commodity chains and global capitalism, Westport, CT: Greenwood Press, 1994.

14 Immanuel M. Wallerstein, World-systems analysis: an introduction, Durham, NC: Duke University Press, 2004. Jennifer Bair and Gary Gereffi, 'Local clusters in global chains: the causes and consequences of export dynamism in Torreon's blue jeans industry', World Development, 29, 2, 2001, pp. 1885-1903; John Humphrey and Hubert Schmitz, 'How does insertion in global value chains affect upgrading in industrial clusters?', Regional Studies, 36, 9, 2002, pp. 1017-27; Frank Pyke and Peter Lund-Thomsen, 'Social upgrading in developing country industrial clusters: a reflection on the literature', Competition and Change, 20, 1, 2016, pp. 53-68; Timothy Sturgeon, Johannes Van Biesebroeck, and Gary Gereffi, 'Value chains, networks and clusters: reframing the global automotive industry', Journal of Economic Geography, 8, 3, 2008, pp. 297321.

15 For business history, see Geoffrey Jones, Entrepreneurship and multinationals: global business and the making of the modern world, Cheltenham: Edward Elgar, 2013; Robert Fitzgerald, The rise of the global company: multinationals and the making of the modern world, Cambridge: Cambridge University Press, 2006; Christopher Bayly, The birth of the modern world, 1780-1914: global connections and comparisons, Oxford: Blackwell, 2004. For global history, see William G. Clarence-Smith and Steven Topik, eds., The global coffee economy in Africa, Asia, and Latin America, 1500-1989, New York: Cambridge University Press, 2003; David Veevers, "IInhabitants of the universe": global families, kinship networks, and the formation of the early modern colonial state in Asia', Journal of Global History, 10, 1, 2015, pp. 99-121; Natasha Glaisyer, 'Networking: trade and exchange in the eighteenth-century British empire', Historical Journal, 47, 2, 2004, pp. 451-76.

16 Charles Jones, International business in the nineteenth century: the rise and fall of a cosmopolitan bourgeoisie, New York: New York University Press, 1987. See also Gregory Barton, Informal empire and the rise of one world culture, Basingstoke: Palgrave, 2014; Manuel Llorca-Jana, 'Shaping globalization: London's merchant bankers in the early nineteenth century', Business History Review, 88, 3, 2014, pp. 469-95. 
A further body of work concentrated on the activity of 'communities of experts', also called 'epistemic communities', 'communities of interest', or 'communities of practice'. ${ }^{17}$ These are defined as cohesive 'groups of knowledge-driven agents linked together by a common goal, a common cognitive framework and a shared understanding of their work'. ${ }^{18}$ They often recognize common practices, formalize their network through associations or institutions, and condense their specialist knowledge through 'manifesto publications'. In the colonial period, these communities comprised mostly Western-educated staff of both private and public institutions. These scientists, researchers, and business people spent their formative years in the colonies, and often moved around the empire during their career. Being part of a white elite, experts, government officials, and business people experienced, de jure or de facto, racial segregation in the colonial context. As they all frequented the same places for 'expats', such as golf or country clubs for social gatherings, they would create durable contacts and dense transnational communities. ${ }^{19}$

The literature widely acknowledged that communities of practice primarily operated on a local or regional scale, often connected to geographically concentrated industrial poles, such as clusters. ${ }^{20}$ For example, Christophe Bonneuil extensively studied the collaboration between scientists in Africa. ${ }^{21}$ His work documented the fact that scientists' involvement often went beyond their area of expertise in companies and public institutions, as they participated in designing policy and directed administrative initiatives that shaped the development of colonial territories. Akami showed that the League of Nations encouraged the cooperation of 'national' public health experts across intercolonial networks, and involved them directly in processes of policy design, institution building, and policy implementation, at both regional and global levels. ${ }^{22}$ This research shows that experts' mobility and connectivity favoured the upgrade and exchange of knowledge within broader transnational networks. However, it does not sufficiently appreciate the fact that the increased mobility and stronger connections of these experts often translated into more options for their personal and professional development.

The palm oil story highlights how interaction within the network of businesses, experts, and colonial officials contributed to the advancement and the partial homogenization of institutions in the two clusters, but this article takes the story a step further. After considering the collaborative impact of increased linkages, mobility, and cohesion among these communities, it evaluates competitive outcomes ensuing from interaction across the two palm oil clusters. Indeed, while improving palm oil production, knowledge exchange between Africa and Asia also fostered competition between the two locations.

17 Patrick Cohendet, David Grandadam, Laurent Simon, and Ignasi Capdevila, 'Epistemic communities, localization and the dynamics of knowledge creation', Journal of Economic Geography, 14, 5, 2014, pp. 929-54; Ash Amin and Joanne Roberts, 'Knowing in action: beyond communities of practice', Research Policy, 27, 2008, pp. 353-69; Etienne Wenger, Communities of practice: learning, meaning, and identity, Cambridge: Cambridge University Press, 1998.

18 Cohendet et al., 'Epistemic communities', p. 929.

19 London Metropolitan Archives, London (henceforth LMA), CLC/B/112/MS37389-90, Recollections of members of staff concerning the history of the company, 1912; Pauline Leonard, Expatriate identities in postcolonial organizations: working whiteness, Burlington, VT: Ashgate Publishing, 2010, ch. 7.

20 Harry Collins, Changing order: replication and induction in scientific practice, London: Sage, 1985.

21 Christophe Bonneuil, 'Development as experiment: science and state building in late colonial and postcolonial Africa, 1930-1970', Orisis, 15, 2000, pp. 258-81; Christophe Bonneuil, 'Penetrating the natives: peanut breeding, peasants and the colonial state in Senegal (1900-1950)', Science, Technology and Society, 4, 1999, pp. 273-302.

22 Tomoko Akami, 'Imperial polities, intercolonialism, and the shaping of global governing norms: public health expert networks in Asia and the League of Nations Health Organization, 1908-37', Journal of Global History, 12, 1, 2017, pp. 4-25. 
This analysis helps to present clusters as backbones of the expansion of global capitalism and as a legacy of colonialism. The case study shows that, rather than being simply vehicles of competitiveness, clusters historically facilitated foreign-managed extractive activities in territories with poor infrastructure. Owing to its more collaborative environment among different parties, such as foreign estate companies, government officials, research institutions, and a dynamic smallholder sector, Southeast Asia emerged as a major threat to the African industry, where the introduction of large-scale foreign estates and collaboration with local farmers were long resisted.

\section{Elæis guineensis between Africa and Asia, 1900s-1920s}

The Second Industrial Revolution fostered an increasing appetite for resources, which became a vital objective of the colonial powers' strategic and political agendas. As a consequence, the second half of the nineteenth century saw a steep increase in the transfer of crops across oceans. Early episodes of what was later controversially named 'biopiracy' were the taking of tea plants and seedlings from China to India by Robert Fortune in 1852, the movement of cinchona (the source of quinine) from the Andean forests by Robert Cross and Richard Spruce in 1860, and the smuggling of Hevea brasiliensis from the Amazon by Henry Wickham in $1876 .{ }^{23}$ These acquisitions allowed European companies, and especially British ones, to expand the cultivation of these commodities in colonial territories with similar climatic features, establishing agricultural clusters in direct competition with locations of origin.

At the end of the nineteenth century, a cluster based on large-scale estates emerged in Southeast Asia following the commercial adaptation of Hevea rubber seedlings from the Amazon. ${ }^{24}$ This was followed by the rapid development of rubber smallholdings. ${ }^{25}$ In less than two decades, Sumatra in the Netherland Indies, and the British-controlled Malay Peninsula, accounted for more than $50 \%$ of global rubber exports. ${ }^{26}$ By the end of the First World War, the Asian cluster had whittled Brazil's rubber market share down to less than $10 \% .{ }^{27}$

Several elements explain the rapid success of Southeast Asia. Attempts to domesticate the rubber crop for estate or farming agriculture in South America had failed on multiple occasions. For instance, Henry Ford infamously tried to vertically integrate his tyre production by creating estates in Brazil in the 1920s. ${ }^{28}$ His failure was primarily due to 'leaf blight', a fungus attacking young Hevea trees and destroying them before they reached maturation. ${ }^{29}$ By some

23 Vandana Shiva, Biopiracy: the plunder of nature and knowledge, Brooklyn, NY: South End Press, 1999.

24 P. R. Wycherley, 'Introduction of the Hevea to the Orient', The Planter, 4, 1968, pp. 1-11; 'Mad Ridley brought us rubber', Straits Times, 6 November 1983, p. 18; http://eresources.nlb.gov.sg/newspapers/Digitised/Article/straitstimes19831106-1.2.68 (consulted 27 April 2018); Valeria Giacomin, 'The emergence of an export cluster: traders and palm oil in early twentieth-century Southeast Asia', Enterprise and Society, forthcoming 2018.

25 Peter T. Bauer, The rubber industry: a study in competition and monopoly, London: Longmans, Green, 1948.

26 John Drabble, Rubber in Malaya 1876-1922: the genesis of the industry, Oxford: Oxford University Press, 1973; John Drabble and Peter Drake, 'The British agency houses in Malaysia: survival in a changing world', Journal of Southeast Asian Studies, 12, 2, 1981, pp. 297-328.

27 Randolph Resor, 'Rubber in Brazil: dominance and collapse, 1876-1945', Business History Review, 51, 3, 1977, pp. 356, 361.

28 Greg Grandin, Fordlandia: the rise and fall of Henry Ford's forgotten jungle, New York: Metropolitan Books, 2009.

29 On South American leaf blight in rubber, see http://www.cabi.org/isc/datasheet/33893 (consulted 27 April 2018). 
miracle, the fungus was never transferred overseas, which paved the way for the rise of rubber cultivation in hospitable Southeast Asian soils and climate. ${ }^{30}$

The major advantage of Southeast Asia was a long tradition in export agriculture of several crops such as sugar, tobacco, coffee, and rice, which meant that rubber producers could make use of the existing physical infrastructure and research institutions. Moreover, in Singapore, the regional commercial centre, a cosmopolitan business community comprising Western, Chinese, Indian, and Hadhrami Arab traders managed the inflow of finance, equipment, and contract labour, and provided producers with specialized services, such as banking, insurance, logistics, marketing, and legal consulting. ${ }^{31}$ In the 1910s, the major Western trading houses vertically integrated into commercial estates. Meanwhile, dynamic non-Western entrepreneurs supported smallholders' development, especially in Sumatra, to expand rubber manufacturing in Singapore. ${ }^{32}$ In this way, the city became the major rubber processing and trading hub, linking the surrounding production areas with international markets and fostering the globalization of regional agriculture. ${ }^{33}$

Finally, planting ventures could benefit from the presence of both public and private research institutions, such as the Singapore Botanical Gardens, the Malayan Agricultural Department, and the AVROS station in Sumatra. ${ }^{34}$ Although large corporations benefited from government support and regulations penalizing smallholdings, colonial institutions generally adopted a laissez-faire approach towards indigenous farmers, and Dutch authorities also developed public research for smallholders over time. These facilitated the process of adaptation of wild crops to settled farming, and supported the sharing and development of agricultural knowledge. Scientific and business institutions, created to domesticate Hevea, were then repurposed for the introduction of the oil palm as an alternative to rubber. ${ }^{35}$

When rubber prices plummeted in the 1920s, the oil palm proved a lucky diversification option, as it was biologically similar to rubber, had a large range of commercial applications, and could be grown in existing rubber estates, which at the time were suffering increased competition from more efficient smallholdings. ${ }^{36}$ At the downstream level, palm oil products proved to be an equally valid substitute, as shipping companies could use existing bulking and shipping infrastructure for liquid products to store and transport palm oil. ${ }^{37}$

30 Food and Agriculture Organization, Protection against South American leaf blight of rubber in Asia and the Pacific region: volume II, Bangkok: FAO, 2012, available at http://www.fao.org/docrep/015/i2730e/ i2730e00.htm (consulted 27 April 2018).

31 Gregg W. Huff, The economic growth of Singapore: trade and development in the twentieth century, New York: Cambridge University Press, 1994; Anthony Reid, 'Early Chinese migration into North Sumatra', in Jerome Ch'en and Nicholas Tarling, eds., Studies in the social history of China and South-East Asia, Cambridge: Cambridge University Press, 1970, pp. 289-321; Ulrike Freitag and William Clarence-Smith, Hadhrami traders, scholars, and statesmen in the Indian Ocean, 1750s-1960s, Leiden: Brill, 1997.

32 William G. Clarence-Smith, 'Rubber cultivation in Indonesia and the Congo from the 1910s to the 1950s: divergent paths', in Ewout Frankema and Frans Buelens, eds., Colonial exploitation and economic development: the Belgian Congo and the Netherlands Indies compared, Abingdon: Routledge, 2013, pp. 193-210.

33 Gregg W. Huff, 'The development of the rubber market in pre-World War II Singapore', Journal of South East Asian Studies, 24, 2, 1993, pp. 285-306.

34 AVROS: Algemeene Vereeniging van Rubberplanters ter Oostkust van Sumatra (General Association of Rubber Planters on the East Coast of Sumatra).

35 Giacomin, 'Emergence of an export cluster'; Tate, RGA history, pp. 455-6; Huff, Economic growth, p. 79.

36 Bauer, Rubber industry.

37 Malcom Falkus, The Blue Funnel legend: a history of the Ocean Steam Ship Company, 1865-1973, Basingstoke: Palgrave Macmillan, 1990; Michael B. Miller, Europe and the maritime world: a twentieth-century history, New York: Cambridge University Press, 2012, p. 121. 
Native to the 'Palm Belt' of Africa (from The Gambia to Angola), the oil palm or Eloeis guineensis was a major income staple for local populations. ${ }^{38}$ Two types of oil can be extracted from the fruit of the oil palm tree: palm oil from the pulp, which has similar uses to soybean and rapeseed oil, and palm-kernel oil from the kernel, which is a substitute for coconut oil. ${ }^{39}$ The tapping of semi-wild oil palm groves was an integral part of the Belt's economy and society. Oil extraction and nut collection were village activities, employing the whole family. Men harvested and transported the fruit, while women extracted the oil. Locals consumed palm oil as food or ointment, tapped sap for palm wine, used the trees' trunk and leaves as construction materials, and burned the exterior of the kernels for fuel. In Nigeria, the oil palm had its own deity, Edjokpa, protecting locals during the extraction phase. ${ }^{40}$

In the nineteenth century, oil palm products sourced from semi-wild groves surfaced as the major export from British West Africa, and were the main regional source of revenue after the abolition of the slave trade. ${ }^{41}$ In Europe, palm products were initially used as industrial lubricants; later, on a larger scale, they were employed in the production of soap, candles, margarine, and cooking fats. ${ }^{42}$

The oil palm reached the Amsterdam Botanical Gardens from Africa in the 1830s. Then the Dutch introduced the first four oil palm specimens in the Botanic Gardens in Buitzentorg (now Bogor), Java, in 1848, from seedlings held in Amsterdam and Mauritius. The first oil palm arrived in British Malaya at the Kew Gardens of Singapore in 1875, either from London seedlings via Ceylon, or from the Javanese progeny. ${ }^{43}$ Although Eloeis had reached Southeast Asia earlier than Hevea, the crop long remained relegated as a decorative element, planted in avenues. ${ }^{44}$ This was due to the stagnating prices of vegetable oils in European markets in late nineteenth century, the prevalence of rubber and other crops in Southeast Asia, and the leadership of African locations as major palm oil exporters. ${ }^{45}$

A Belgian agronomist and entrepreneur, Adrien Hallet, was the first to spot the potential of the oil palm as an estate crop in Asia. The founder of the Hallet Group, and later a major shareholder in the plantation company Socfin (Société Financière des Caoutchoucs), Hallet initially worked with oil palms in the Congo Free State (later Belgian Congo) from $1885 .{ }^{46}$ Then, at the turn of the century, as a 'rubber mania' developed, he invested in rubber estates in Sumatra and Malaya. ${ }^{47}$ Reckoning that oil palms would thrive in the region, Hallet launched

38 B.O.W.K., 'Palm oil “chop”: a delectable alternative to curry', The Planter, 8, 1925, p. 219.

39 Francis In and Brett Inder, 'Long-run relationship between world vegetable oil prices', Australian Journal of Agricultural and Resource Economics, 41, 4, 1997, pp. 455-70. The typical ratio of palm kernel to palm oil is $1: 10$.

40 S. O. Aghalino, 'British colonial policies and the oil palm industry in the Niger Delta region of Nigeria, 19001960', African Study Monographs, 21, 1, 2000, p. 22.

41 Martin Lynn, Commerce and economic change in West Africa: the palm oil trade in the nineteenth century, Cambridge: Cambridge University Press, 1997.

42 Janice Henderson and Daphne Osborne, 'The oil palm in all our lives: how this came about', Endeavour, 24, 2, 2000, pp. 63-8.

43 Edmond Leplae, Le palmier à huile en Afrique: son exploitation au Congo Belge et en Extrême-Orient, Brussels: Librairie Falk Fils, 1939.

44 K. G. Berger and Susan M. Martin, 'History of palm oil', in Kenneth Kiple and Kriemhild Ornelas, eds., The Cambridge world history of food, Cambridge: Cambridge University Press, 2000, pp. 397-411.

45 Lynn, Commerce and economic change, p. 111.

46 William G. Clarence-Smith, 'The Rivaud Hallet plantation group in the economic crises of the interwar years', in Pierre Lanthier and Hubert Watelet, eds., Private enterprises during economic crises: tactics and strategies, Ottawa: Legas, 1998, pp. 117-32.

47 John Drabble, 'The plantation rubber industry in Malaya up to 1922', Journal of the Malaysian Branch of the Royal Asiatic Society, 40, 1, 211, 1967, pp. 52-67; Tate, RGA history, pp. 453-4. 
the first oil palm estate in the Sumatran province of Deli in 1911. He also made contact with two French planters, Franck Posth and Henri Fauconnier, and supported the listing of their oil palm estate in Selangor, the first in Malaya, which started operations in $1917 .{ }^{48}$ Taking advantage of the Dutch 'open-door policy' to foreign investment in Sumatra, and of the rubber institutions and infrastructure, Hallet was able to advance domestication faster in Asia, bypassing the difficulties of plantations in Africa. ${ }^{49}$

In Southeast Asia, agricultural production had long been based on estates and efficient smallholdings oriented to export. ${ }^{50}$ However, the palm was a stranger crop, associated with colonial influence, while the locals preferred coconut oil for cooking, and tapped different palms for alcohol and sugar. ${ }^{51}$ Conversely, in Africa, palm oil was a major source of revenue and sustenance, and the domestic market absorbed about half of local production. ${ }^{52}$ Foreign involvement in monocrop estates in Africa was seen as a threat to smallholdings.

As for the organization of production, African locations lagged behind in terms of labour supply and infrastructure. ${ }^{53}$ In Southeast Asia, several public and private institutions managed a continuous inflow of migrant 'coolies' from India, China, and Java to work in estates. ${ }^{54}$ Many of these workers would then disengage from estates, using their experience to start their own plots. ${ }^{55}$ In Africa, local people associated plantation work with slave labour and sourced the oil independently from semi-wild groves, which posed a major hurdle to the private recruitment of harvesters. ${ }^{56}$ Historically, the territory had been exploited as a reservoir of slaves, and therefore it lacked infrastructure, such as roads and railways, to transport agricultural produce in bulk, and to set up large-scale operations. ${ }^{57}$

As a major palm oil buyer, the British soap manufacturer William Lever (later Lord Leverhulme) sought to obtain exclusive land concessions in British West Africa. From 1906, his company, Lever Brothers, started lobbying to establish estates, which in turn would support investment in local processing mills. ${ }^{58}$ While the colonial government had been fairly supportive of foreign investment in plantation in Southeast Asia, ${ }^{59}$ in British West Africa

48 Charles W. S. Hartley, The oil palm, London: Longmans, Green, 1967, pp. 21-2; Martin, UP saga, pp. 46-9; Leplae, Le palmier à huile, pp. 24-5.

49 Anne Booth, 'Varieties of exploitation in colonial setting', in Ewout Frankema and Frans Buelens, eds., Colonial exploitation and economic development: the Belgian Congo and the Netherlands Indies compared, Abingdon: Routledge, 2013, pp. 60-87.

50 William G. Clarence-Smith and François Ruf, 'Cocoa pioneer fronts: the historical determinants', in William G. Clarence Smith, ed., Cocoa pioneer fronts: the role of smallholders, planters and merchants, Basingstoke: Macmillan, 1996, pp. 1-22.

51 Kian-Wie Thee, Plantation agriculture and export growth: an economic history of East Sumatra, 1863-1942, Jakarta: National Institute for Economic and Social Research, 1969.

52 Allister E. Hinds, 'Government policy and the Nigerian palm oil export industry, 1939-49', Journal of African History, 38, 3, 1997, pp. 459-78; David Meredith, 'Government and the decline of the Nigerian oil-palm export industry, 1919-1939', Journal of African History, 25, 3, 1984, pp. 311-29.

53 Tate, RGA history, pp. 453-4, referring to Hallet's Congo operations; Gerald K. Helleiner, Peasant agriculture, government, and economic growth in Nigeria, Homewood, IL: Richard D. Irwin, 1966, p. 9.

54 Ng Siew Yoong, 'The Chinese Protectorate in Singapore, 1877-1900', Journal of Southeast Asian History, 2, 1, 1961, pp. 76-99.

55 Clarence-Smith, 'Rubber cultivation', p. 202.

56 Valerie Johnson, 'Sowing the seeds of nationalism: empire, culture and British business', XIV International Economic History Congress, session 94, Helsinki, 2006, pp. 1-29.

57 N. H. Stilliard, 'The rise and development of legitimate trade in palm oil with West Africa', MA thesis, University of Birmingham, 1938.

58 Nworah D. K., 'The politics of Lever's West African concession, 1907-1913', International Journal of African Historical Studies, 5, 2, 1972, pp. 248-64.

59 Booth, 'Varieties of exploitation', pp. 60-87. 
(especially Nigeria) scepticism towards Lord Lever's endeavours combined with a widespread opposition to plantation schemes among colonial officials through the 1930s. ${ }^{60}$

Despite lobbying to obtain large-scale estates, Lever Brothers was only able to secure planting concessions and processing facilities in a few scattered locations before the Second World War. ${ }^{61}$ The company obtained the former German 'Ndian oil estate (2,300 ha) in the Cameroons as auctioned enemy property in 1924, and Sapele and Calabar oil palm estates (4,800 ha in total) were added to existing (rubber) estates in Nigeria in the early 1930s. Despite these land concessions, colonial officials remained generally wary of any plan forcing local people out 'from their present status of free producers to that of labourers for wages', and refused to grant purchasing monopolies over vast land tracts. ${ }^{62}$

In 1911, Lever enjoyed better luck in the Belgian Congo, where he obtained vast concessions and launched his palm oil subsidiary, Huileries du Congo Belge (HCB). ${ }^{63}$ Yet in this period, Congo was no less of a challenging business environment than the British colonies, as Africans were highly mobile within the concessions, tended to be hostile towards foreign investors, and were reluctant to serve consistently as plantation workers. ${ }^{64}$ Thus, although exports steadily increased, thanks to the colonial government's support, HCB had to rely primarily on natural palm groves, which affected profitability until the post-war period. ${ }^{65}$ The lack of wage labour and the inadequate infrastructure also constrained Socfin's expansion in Belgian Congo, whose operations were deemed 'less of an asset' compared to those in Southeast Asia. ${ }^{66}$ The company's subsidiary, Palmeraies Congolaises, struggled to hire a workforce for their large concessions in Upper Congo, as skilled harvesters, when available, 'preferred to work their own crops to being employed for low wage'. ${ }^{67}$

In contrast, in Asia, oil palm development could benefit from the synergies offered by the rubber cluster in terms of collaboration within the industry and with the government, ensuring a more fluid circulation of knowledge and sharing of best practice. ${ }^{68}$ Further, through mechanical processing, Sumatran producers were able to obtain higher-quality oil, with a lower content of fatty acid. ${ }^{69}$ In sum, while Southeast Asian agriculture was already organized for export, the original cluster in Africa presented structural hurdles for profitable investment

60 Usoro, Nigerian oil palm industry, pp. 36-40; Johnson, 'Sowing the seeds', pp. 1-29; Lord Lugard, 'British policy in Nigeria', Africa: Journal of the International African Institute, 10, 4, 1937, p. 395.

61 Hinds, 'Government policy', p. 471; Frederick Pedler, The lion and the unicorn in Africa: United Africa Company, 1787-1931, London; Heinemann Educational Books, 1974, p. 245; David K. Fieldhouse, Merchant capital and economic decolonization, Oxford: Clarendon Press, 1994.

62 W. G. Ormsby-Gore, Report by the Hon. W.G.A. Ormsby Gore, M.P. (Parliamentary Under-Secretary of State for the Colonies), on his visit to West Africa during the year 1926, London: HMSO, 1926, pp. 107-8. This also explains why Lord Lever eventually turned to Belgian Congo in order to obtain land concessions.

63 Unilever Archives, Port Sunlight, UK (henceforth UL), UAC/2/36/1/7/2, HCB Convention, 1966; UL, UAC/2/ 36/6/1/1, History of Huilever, 1960; F. Kindela, Etudes des filières huile de palme et caoutchouc, Rapport d'Etape I, Groupement AGRER, EARTH Gedif, 2005; David K. Fieldhouse, Unilever overseas: the anatomy of a multinational 1895-1965, Hoover Institution Publication 205, Stanford, CA: Croom Helm, 1978.

64 Fieldhouse, Unilever overseas, pp. 503-9; Benoît Henriet, “"Elusive natives”: escaping colonial control in the Leverville palm oil concession, Belgian Congo, 1923-1941', Canadian Journal of African Studies, 49, 2, 2005, pp. 339-61.

65 Pedler, Lion and the unicorn, pp. 175, 181.

66 Clarence-Smith, 'Rivaud Hallet', p. 127.

67 Ibid., p. 122.

68 The (British) National Archives, London (henceforth TNA), CO/96/670/4, Auchinleck's notes on Sumatra, 1928; Tate, RGA history, pp. 388, 457, 459-61.

69 Chong-Yah Lim, Economic development of modern Malaya, London: Oxford University Press, 1967, pp. 128-9, 135-36. 
in palm oil, in terms of infrastructure, labour recruitment, and government attitudes. In 1924 the major US oil buyers switched from the African oil to the higher-quality Sumatran product and by the mid 1920s British government officials in West Africa started referring to Southeast Asia's growing palm oil exports as 'the Eastern menace'. ${ }^{70}$

\section{Communities of experts and palm oil knowledge exchange, 1920s-1940s}

Despite direct competition between the two clusters, during the interwar period the development of palm oil production was carried out in both locations via continuous contact and knowledge exchange among businessmen and scientists. This laid the foundations for a transnational community of palm oil experts, operating in both private and public organizations. Information travelled both ways, as Asian advances could be enriched by African knowledge on palm varieties and experience in downstream phases of the supply chain.

In the 1920s, faced with the steep erosion of West Africa's share of palm oil exports in the world, the British colonial government started debating how to include foreign investors to promote development. ${ }^{71}$ While supporting the introduction of mechanical presses for oil extraction, and the intensification of research, the government resisted supplementary requests to assist foreign-managed plantations. ${ }^{72}$ The colonial strategy instead focused on initiatives to improve farmer productivity, such as the provision of improved seedlings and the partial mechanization of oil extraction.

In 1926, C. G. Auchinleck and H. B. Waters, officers of the agricultural departments of Gold Coast and Nigeria respectively, were sent to visit Sumatra, Java, and Malaya, with the explicit purpose of studying how to improve the oil palm industry. Coordination among experts across colonies facilitated easy access to information in both Malaya and the Netherland Indies. As mentioned in a dispatch to the Foreign Office from the Consul in East Sumatra: 'Both Officers spoke highly of the courteous assistance offered to them by the Dutch Officials and the technical experts, with whom they came in contact. ${ }^{73}$ Moreover, in his report of the visit, Auchinleck highlighted an inclusive research environment in Southeast Asia, where knowledge circulated among scientists across Southeast Asian colonial territories. ${ }^{74}$ Through this visit, the experts from Africa liaised with the Southeast Asian network of planters, such as the leading AVROS researchers Dr A. W. K. de Jong and Dr A. L. Rutgers, and Socfin's chief researcher M. Ferrand.

This same kind of coordination and exchange of scientific research proved more difficult across different colonial jurisdictions in Africa. British West Africa and the Belgian Congo hosted several state-sponsored research centres such as the agricultural departments of Nigeria and the Gold Coast, the Institut National pour l'Étude Agronomique du Congo Belge (INEAC) in Mongana and Yangambi, and the local botanical gardens, which launched programs on

70 Usoro, Nigerian oil palm industry, p. 41, n. 35; Clarence-Smith, 'Rivaud Hallet', p. 122; Tate, RGA history, p. 465, n.14. TNA, CO/879/122, 'Palm oil industry in West Africa', 1932.

71 Meredith, 'Government', p. 313.

72 Ukegbu, 'Production', pp. 210-23; Hinds, 'Government policy', p. 471.

73 TNA, CO/554/71/2, 'Palm oil expedition to Sumatra', 1926.

74 TNA, CO/96/670/4, C. G. Auchinleck's notes on Sumatra, 1928. 
palm progeny and seed selection from the mid 1920s. In 1927, the first West African agricultural conference took place in Ibadan. ${ }^{75}$

However, in 1929, the Nigerian government rejected the proposal of establishing an oil palm research station, although the UK was funding agricultural research in several imperial locations. ${ }^{76}$ Meredith considers that the scale of 'research was modest during the 1920 s and virtually non-existent in the 1930 s' ${ }^{77}$ Agricultural departments started carrying out 'serious research' only in 1928, and 'the scale of operations was negligible until 1937'. ${ }^{78}$ Direct cooperation between scientists in British territories and in the Belgian Congo only took off in the late 1930s, when the Malayan Agricultural Department sent its oil palm botanist F. W. Toovey to visit the research facilities and organization of the industry in Belgian Congo. Meanwhile Unilever's local arms, the United Africa Company (UAC) (created from the consolidation of Lever's West African interest in 1929) and HCB, only started exchanging research findings in the early 1940s. ${ }^{79}$

In the 1930s, colonial governments realized the urgency of improving native farmers' productivity and oil quality, without imposing plantations. ${ }^{80}$ Thus, they started linking smallholder schemes to mechanization. ${ }^{81}$ UAC provided seeds free of charge to the colonial government, and attempted to fund replanting schemes, in the hope of obtaining further estate concessions. ${ }^{82}$ However, attempts at introducing oil presses and quality control in villages mostly failed, because of high prices of equipment and fierce opposition from local women, who found themselves deprived of their major source of revenue and independence. ${ }^{83}$ Similarly, the government started to push palm-planting schemes at the same time as it introduced direct taxation. Local producers saw a connection between the two, and responded with scepticism and resistance. ${ }^{84}$ By the 1940s, large-scale estates in Nigeria still accounted for only $2.3 \%$ of exports. ${ }^{85}$

Overall, these efforts did not automatically translate into higher yields, greater engagement of indigenous farmers, or improved exports from British West Africa compared to competitors. However, in Cameroon, the African and Eastern Trade Corporation's estates proved successful early on, as they 'had eyes on the Far East, and had taken up all ideas of plant breeding, improved agricultural methods and manuring. ${ }^{86}$

Unlike Southeast Asia, where research was constantly tested on estates and easily passed on to the private sector, in Africa there was no systematic way of implementing research upstream, or spreading it consistently among farmers. This was due to a lack of sound collaboration and

75 Proceedings of the first West African agricultural conference, Lagos: Government Printer, 1927.

76 Meredith, 'Government', p. 324

77 Ibid., p. 323.

78 TNA, CO/852/601/11, 'Report on palm oil commercial agriculture in Africa', 1945.

79 TNA, CO/852/601/12, Report on oil palm research in Africa - letter to the INEAC chemist Oswald Roels, 1945; Ukegbu, 'Production', p. 273.

80 Martin Kaniki, 'Economical technology against technical efficiency in the oil palm industry of West Africa', Development and Change, 11, 2, 1980, pp. 273-84.

81 TNA, CO/267/619, 'Oil palm in Sierra Leone', 1928; TNA, CO/96/690/15, 'Mill development in the Gold Coast', 1929; TNA, CO/879/122, 'Palm oil industry in West Africa', 1932, pp. 56-7, 84, 97; UL, UAC/1/2/3/ 4/1, 'Report on palm oil improvement in Africa', 1936.

82 Meredith, 'Government', p. 325; Hinds, 'Government policy', pp. 471-5.

83 Martin, Palm oil and protest, ch. 9.

84 Ukegbu, 'Production', pp. 301-8.

85 Fieldhouse, Merchant capital, pp. 204-8; Meredith, 'Government', p. 319, quoting Nigeria trade report for 1939.

86 Pedler, Lion and the unicorn, p. 249. 
communication across different cluster stakeholders, as farmers, the colonial government, and European merchants all remained suspicious of each other, having their own ideas on how to improve the industry. ${ }^{87}$

Conversely, oil palms made great strides in the Asian cluster. Socfin, together with the agency house Guthrie and the small Danish estate company United Plantations (UP) in Malaya, employed several scientists, initially working on rubber, to pioneer research projects on oil palm seed selection and processing techniques. Moreover, they could call on the support and informal coordination of the two leading agricultural research centres, AVROS in Sumatra and the Serdang Agricultural Department in Malaya. ${ }^{88}$ The results of this research activity were then collected, codified, and made widely available by the Incorporated Society of Planters (ISP) in Kuala Lumpur, through publications and its scientific journal, The Planter, which became the preferred outlet for the dissemination of specialized knowledge on the oil palm crop from 1923. During the 1920s, the ISP organized its first conference, inviting leading agronomists such as C. D. V. Georgi and B. Bunting, members of the Serdang team. ${ }^{89}$ This interrelation and proximity between public and private spheres in Asia yielded a cohesive community of practice at the regional level, with strong links with London and Africa.

As a result, some of the innovations developed in Africa found quicker and more efficient application in Asia. The issue of palm progeny is illustrative in this regard. The most popular palm in Africa was the Dura variety, which typically had a large shell and a thin pericarp. Most oil palms that reached Southeast Asia were of this kind: particularly fleshy and vigorously fruitful. Early selection work in the Sumatran Deli province had produced a variety with a tender shell and a richer pulp, called 'Deli-Dura'. Before the Second World War research stations in both Africa and Asia carried out breeding programmes to select easier-to-harvest dumpy palms, yielding fruits with larger flesh to kernel proportions, and a softer shell. In the early 1920s, AVROS ran several propagation programmes based on seeds of Tenera palms, a rarer variety with thin shell and pulpy fruit, obtained from the Eala Botanical Gardens in Congo. ${ }^{90}$ Being a major player in both regions, Socfin could channel knowledge in both directions. ${ }^{91}$ In his report, Auchinleck mentions that Socfin 'has kindly undertaken to forward 200 seeds, from selected [Sumatran] bunches ... for trial in the Gold Coast' and that it imported selected seed for small-scale planting in the Ivory Coast. ${ }^{92}$ In the 1930 s, the doyens of oil palm breeding, Dr A. Beirnaert and R. Vanderweyen at the INEAC in Yangambi (Belgian Congo), ran a three-year programme on Tenera progeny, reaching the path-breaking conclusion that the variety was a cross between the popular Dura and the rare shell-less Pisifera. ${ }^{93}$ These breakthroughs were immediately incorporated in Asia, where planters scrambled to obtain Pisifera seeds. ${ }^{94}$ In general, despite the quality of research personnel and facilities in

87 Hinds, 'Government policy', p. 471; Meredith, 'Government', p. 318.

88 Tate, RGA history, pp. 454-7; Geoffrey Jones, Renewing Unilever: transformation and tradition, Oxford: Oxford University Press, 2005, pp. 200-2.

89 LMA, CLC/B/112/MS37394/004, Nickalls' Papers, notes on post-war rehabilitation, 1989.

90 Martin, UP saga, pp. 53, 143.

91 Clarence-Smith, 'Rivaud Hallet', p. 123.

92 TNA, CO/96/670/4, Auchinleck's notes on Sumatra, 1928, p. 16; Clarence-Smith, 'Rivaud Hallet'.

93 A. Beirnaert and R. Vanderweyen, Contribution à l'étude génétique et biométrique des varieties d'Elaeis guineensis, Brussels: Jacquins' Publications de l'INEAC, 1941.

94 Martin, UP saga, p. 144. 
Africa, palm seeds ended up being sent to Asia for further selection, breeding, and most importantly testing, and only eventually came back to Africa. ${ }^{95}$

African innovations proved very successful in Asia at other stages of the supply chain. In the 1920s, Socfin was the first to open a bulking facility for shipment to Europe in Belawan (Sumatra), introducing a tank system for palm oil storage, modelled on the one devised by Unilever for its Congo operations. ${ }^{96}$ Headed up by Guthrie, Malaysian producers followed suit, financing a joint bulking facility in Singapore in $1932 .{ }^{97}$

Overall, the African cluster suffered from the rise of a better organized and more priceefficient Asian cluster, in a time of fierce competition in oil markets (including whale oil) and laissez-faire attitudes in the UK. ${ }^{98}$ In British West Africa the bulk of farmers' production was directed to the domestic market, while the colonial administration long remained wary of foreign involvement in upstream palm oil production. ${ }^{99}$ In Congo, when HCB shifted to nominal control by UAC in 1933, the company was developing commercial estates. ${ }^{100}$ While by 1931 HCB's holdings 'were not real plantations yet', the company could call on the large scope of action of UAC in the region and its research cooperation with the cutting edge work of the INEAC team. ${ }^{101}$ Only in 1937, did HCB obtain the green light to develop 100,000 acres of oil palm estates before the mid 1950s.

Meanwhile, in 1936, Sumatra surpassed Nigeria in palm oil exports and, together with Malaya, came to account for half of global exports in $1939 .{ }^{102}$ This could have marked the end of the African industry, but two elements concurred to prolong the coexistence of the two clusters. First, the Japanese occupation of Southeast Asia, and the subsequent decolonization process in Indonesia, downsized Sumatran and Malaysian capacity, if only temporarily, and reversed their recently achieved global dominance as palm oil exporters. This created renewed pressure for more efficient smallholder agriculture in Africa, to secure food provisions in Britain. ${ }^{103}$ On the internal front, the fact that West Africa's farmer production concentrated on kernels, while Asia specialized in oil from palm fruit, helped the location of origin to keep a foothold in international markets. ${ }^{104}$ In this context, Unilever's subsidiaries seized the opportunity to scale up their estate operations after four decades of substantial investment in palm oil research. ${ }^{105}$

95 Stephanie Kerckhofs and Yves Segers, 'Crisis in de tropen. Landbouwpolitiek en agrarische wetenschap in Belgisch Congo, c. 1900-1940 (Crisis in the tropics: agricultural policy and agricultural science in Belgian Congo (c.1900-1940))', in Bruno Blondé, Hilde Greefs, Ilja Van Damme, Maarten Van Ginderachter, and Henk de Smaele, eds., Overheid en economie: geschiedenissen van een spanningsveld (Government and economy: history of a field of tension, Antwerp: University Press Antwerp, 2014, pp. 133-52.

96 TNA, CO/96/670/4, Auchinleck's notes on Sumatra, 1928, p. 32; Martin, UP saga, p. 68; 'Shipment of palm oil in bulk', The Planter, 11-12, 1931, pp. 353-4.

97 Guthrie Collection, SOAS Archives, London (henceforth GC), 20/06-07, 'Oil palms of Malaya', Journal 1 and 2, 1930-3.

98 Ayodeji Olukoju, 'The United Kingdom and the political economy of the global oils and fats business during the 1930s', Journal of Global History, 4, 1, 2009, pp. 105-25.

99 Ukegbu, 'Production', pp. 355, 377-82.

100 Fieldhouse, Merchant capital, p. 222; Fieldhouse, Unilever overseas, p. 494.

101 Fieldhouse, Merchant capital, p. 206; Martin, UP saga, p. 143; Kerckhofs and Segers, 'Crisis in the tropics', p. 142.

102 Usoro, Nigerian oil palm industry, p. 48.

103 Hinds, 'Government policy', p. 465.

104 Olukoju, 'United Kingdom', p. 121.

$105 \mathrm{UL}, \mathrm{UAC} / 1 / 2 / 3 / 4 / 1$, 'Report on palm oil improvement in Africa', 1936. 


\section{The uncertain fate of palm oil after the Second World War, mid 1940s-mid 1950s}

The Second World War marked a watershed in the global competitive dynamics of palm oil production. Between 1941 and 1945, the Japanese army occupied both the Malay Peninsula and the Netherland Indies. They redirected much land to food production, maintaining about $44 \%$ of rubber estates under Asian management to supply their war effort. ${ }^{106}$ In the post-war period, knowledge spread primarily through private actors and independent research stations. Asian colonial institutions lost influence, as European powers funded them less following the war. Prior to the war, colonial institutions, Western corporations, and service-oriented cities, such as Singapore and London, had coordinated the exchange of financial capital, technology, and agricultural knowledge from Africa to Southeast Asia, and vice versa.

Independently, Singapore lost ground to Malaya. This was partly due to a contraction in global trade, but also to increasing nationalism in the region. Agricultural supplies from the city's strategic source of trading, Sumatran smallholders, also decreased, following political turmoil in Indonesia and President Sukarno's radical economic policies. ${ }^{107}$ In contrast, Malaya, which in 1938 had accounted for only $10 \%$ of global palm oil exports, found itself in a middle-ground position. Between 1946 and 1952, the British Ministry of Food committed to buying all palm oil supplies from its former colonies, favouring those few rubber producers that had started diversifying into palm oil before the war, grouped into the Malaysian Palm Oil Pool. ${ }^{108}$ The Serdang Department, directed by the energetic Erik Rosenquist, launched a promising breeding programme, based on West African Tenera seeds, and distributed planting material among Rosenquist's personal network of foreign planters. However, the outburst of civil conflict, the 'Emergency', made Western estates targets of guerrilla attacks up to the mid 1950 s, retarding the resumption of export agriculture.

In this period, the oil palm did not have a specialized research station in Malaya. The Rubber Research Institute of Malaya could not allocate funds to research non-rubber crops, as by that time it was investing all its resources in countering the threat from synthetic rubber. Further, owing to political instability and the declining means available to the Serdang Department from the early 1950s, Rosenquist resigned to join Guthrie's independent station in 1954. ${ }^{109}$ Hence, Southeast Asia temporarily lost its leadership in palm oil exports, leaving room for African 'pilot' plantations and local farmers to catch up.

During the 1940s, Nigeria regained its primacy in palm oil export markets and its role of global pole for palm oil experts (see Figure 1). In 1938, the Oil Palm Research Station (WAIPOR) had been established in Benin to complement the work of the Nigerian Agricultural Department in Ibadan. ${ }^{110}$ In 1949 the Nigerian Oil Palm Produce Marketing Board was

106 TNA, CO/852/670/12, 'Post war condition of Malayan estates', BNA Report, 1945; Gregg W. Huff and Shinobu Majima, World War II Singapore: the Chōsabu reports on Syonan, Singapore: National University of Singapore Press, 2018.

107 LMA, CLC/B/112/MS37394/005, Nickalls' Papers, F. W. Harper's notes on Indonesia; Huff, Economic growth, table 10.2, p. 285. LMA CLC/B/112/MS37394/004, Nickalls' Papers, post-war rehabilitation, 1989; Nicholas White 'Surviving Sukarno: British business in post-colonial Indonesia, 1950-1967', Modern Asian Studies 46, 5, 2012, pp. 222-42; Thomas Lindblad, Bridges to new business: the economic decolonization of Indonesia, Leiden: Brill, 2008.

108 Valeria Giacomin, 'Negotiating cluster boundaries: governance shifts in the palm oil and rubber cluster in Malay(si)a (1945-1970 ca.)', Management and Organizational History, 12, 1, 2017, pp. 76-98.

109 Martin, UP saga, p. 149.

110 TNA, CO/852/601/12, 'Report on oil palm research in Africa', 1947. 
established, and it granted WAIPOR continued financing through the 1950s. In 1949 WAIPOR also hosted the first oil palm conference, reuniting leading scientists and palm oil experts employed in UAC facilities and public research centres in both West Africa and Congo. ${ }^{111}$ Of representatives from other continents, the only ones invited were B. S. Gray, a palm oil expert at Guthrie's Chemara estates, and two Dutch researchers.

The increased productivity of smallholder agriculture and the novel government support for estates created a more cohesive environment in the African cluster. Seeing its long-time ambition finally materializing, in the early 1940s UAC launched the Pioneer Oil Mills project, donating a small processing plant to the government for the use of local farmers. Although the government expansion of UAC's initiative led to improved oil quality, after a decade the Pioneer Mills had shown a disappointing rate of progress, representing only $5 \%$ of Nigeria's exports in $1953 .{ }^{112}$ Equally disappointing was the attempt by the British-sponsored Colonial Development Corporation to launch estate schemes in the Nigerian Calabar division, which in the 1950 s started reporting problems of cooperation with settlers. ${ }^{113}$

Nevertheless, between 1946 and 1957 local farmers' palm oil production more than doubled, from 101,000 tons to 208,000 tons. This was due to improved regulatory incentives, combined with a general shift in mentalities. The Marketing Board gave maximum priority to improved oil quality. ${ }^{114}$ Thus, in 1951 it introduced differential pricing for palm oil grades, similar to the system long in use in Asia. ${ }^{115}$ Moreover, after the war, farmers started to see mechanization as a sign of modernization, recognizing the value of mills in producing higherquality oil and in enhancing the welfare of the villages where they were in use. ${ }^{116}$

In sum, between the 1940s and the mid 1950s, while West Africa regained ground as a stronghold of palm oil production, in Malaya the fate of the commodity was still uncertain. At this stage, the two locations seemed to be competing on equal terms. Despite the feeling of insecurity during the Emergency, Malaya presented a more collaborative institutional environment, stronger linkages with services, and higher yields. ${ }^{117}$ However, the territory was still a novice in palm oil production.

In Africa, notwithstanding post-war progress, the business environment left much to be desired, especially in the eyes of investors accustomed to operating in Asia. Nonetheless, amid post-war insecurity, British companies with estates in Asia started looking for new investment opportunities in Africa. For instance, in the early 1950s, Barlow invested in rubber estates in Nigeria, but soon recognized the disadvantages of the location. In a letter to J. H. Tovey, the director of Barlow's estates in Malaya, John Barlow compared the two locations: 'we do not know how lucky we are in Malaya ... the thing that impressed me the most was the tremendous advantages of planting in Malaya where you have good labour and excellent subordinate staff'. In contrast, he lamented that, in Nigeria:

111 TNA, CO/852/1156/6, 'Oil palm research international conference in Benin', 1949.

112 Peter Kilby, The Nigerian palm oil industry, Stanford, CA: Food Research Institute, Stanford University, 1967; Ukegbu, 'Production', pp. 390-2, 399.

113 Ukegbu, 'Production', p. 402-5.

114 Kilby, Nigerian palm oil industry, pp. 185-7.

115 Ibid., pp. 415-17; Usoro, Nigerian oil palm industry, p. 85.

116 Aghalino, 'British colonial policies', p. 29.

117 UL, UAC/1/1/1/12/865, 'Report on Kluang extension', 1949. 
I was disappointed to note the general lack of faith in the country. Interest rates for longterm development seem to me to be prohibitive ... The territory has been promised independence in 1956 and, so far, the local politicians show no signs of being competent to accept this responsibility ... The corruption and bribery which goes on throughout the country is most disturbing. ${ }^{118}$

At the same time, the major estate companies in Malaya took steps to resume their oil palm research and their pre-war links with African institutions. Since the mid 1940s, Guthrie and UP had established informal communication with HCB in Congo. ${ }^{119}$ In the early 1950 s, Harrison and Crosfield (H\&C) was the first to convert its coastal rubber estates to oil palms. In 1955, it created an independent oil palm research station at the Dusun Durian estate in Selangor, working on non-rubber crops in close contact with the experienced planter Tom Fleming, at H\&C's surviving Sumatran estates. ${ }^{120}$

Despite the advantage achieved during the war, Africa was still a difficult environment for multinationals to operate in. Unilever had scaled up its investment in research in its African locations on all stages of planting and processing, but its long-time ambition of large-scale estates did not materialize. ${ }^{121}$ Thus, the company opted for diversifying geographically towards Asia. In 1947, the corporation acquired 4,000 acres in Kluang, in Malaya's Johore State, and it eventually expanded its Asian presence over the decade, adding an additional 6,000 acres, and cultivating new land in Sabah. ${ }^{122}$

By 1960, Unilever's oil palm estates covered 11,400 acres, around $10 \%$ of the total acreage on the Malay Peninsula, but less than $10 \%$ of its combined (semi-wild) acreage in Congo $\left(140,000\right.$ acres) and Nigeria (34,000 acres). ${ }^{123}$ As a point of reference, in 1957 the total acreage in Malaya was already 7,000 acres, $15 \%$ of the company's total world acreage; in 1964 it was 12,000 acres.

In Southeast Asia, Unilever could test and improve the result of its long-standing African research and development investment, and even use it to carve out a leadership position in the still resurrecting region. As reported in the minutes from meetings of Unilever's special committee:

Mr. de Blank [the head of research] had come away with the impression that neither the Dutch nor the British in Malaya were in advance of our research and technical practice in the Congo and Nigeria with the exception of the money being spent on fertilizing. ... [W] hile this was satisfactory from one point of view it was disappointing to the extent that we had hoped to learn something from them. ${ }^{124}$

118 Barlow Collection, Cambridge University Library, UK (henceforth BC), JDB/1198, Correspondence with Malayan estates, John Barlow to J. H. Tovey, 5 March 1953.

119 Martin, UP saga, p. 150.

120 LMA, CLC/B/112/MS37394/004(1), Nickalls' Papers, notes on post-war rehabilitation, 1953; Tate, RGA history, p. 594.

121 Martin, UP saga, p. 188.

122 UL, UNI/BD/SC/1/460-62, Minutes of the Special Committee with the Plantation Executive, 1950, p. 5, 1960, p. 4; Fieldhouse, Merchant capital, p. 220; Martin, UP saga, p. 188.

123 UL, UAC/1/2/4/19/11, 'Report on research in Africa', 1957, p. 551; UL, UNI/RM/OC/2/2/64/58, Kluang investment, 1964.

124 UL, UNI/BD/SC/1/460, Minutes of the Special Committee with the Plantation Executive, 1957, p. 5. 
Indeed, as John Barlow observed, UAC had been 'very secretive' about the condition of their estates in Nigeria, whereas, once in Asia, the company traded its know-how to establish a foothold in the region. ${ }^{125}$ For instance, Unilever researched production and storage of palm oil in collaboration with INEAC, and made the findings of the resulting Mongana report widely available in Southeast Asia. ${ }^{126}$ Thanks to its liaison with B. S. Gray, the corporation employed the major palm oil producer in Malaya, Guthrie, as managing agent and consultant, cooperating with the company's Chemara research facilities. The transfer of knowledge across locations further improved after 1955, when Unilever aggregated all its agribusiness investments under the umbrella of a single organization, the Plantation Group, managed by the executive D. L. Martin. ${ }^{127}$

\section{Unilever and the Southeast Asian palm oil boom, 1950s-1960s}

Whereas in the immediate post-war period Africa drove the development of palm oil production, after Malaysia's independence from Britain in 1957, leadership shifted to the Asian cluster, with Malaysia emerging as the primary global producer of palm oil. Although Malaysia went through significant turbulence at the regional level in the early 1960s, the new government remained officially supportive of foreign investment. ${ }^{128}$ Simultaneously, the political situation in Congo and Nigeria quickly deteriorated, leading to a sharp decline in estate output. Unilever's Plantation group had been channelling knowledge and resources from Africa to Asia for more than a decade, but Malaysia's relative political stability and stronger institutions were the key factors that led to its global dominance as palm oil exporter. By 1958 , all the big rubber producers on the Malay Peninsula had realized the potential of opening up oil palm estates on a large scale in the region, and were converting their rubber acreage. ${ }^{129}$

In 1956, the Malayan government established the Federal Land Development Authority (FELDA), a public agency linking the privately controlled estate system to the indigenous farmers. FELDA was in charge of the distribution of available land to local farmers, the subsequent development of smallholdings for different crops, and the provision of specialized services to connect them with international markets. ${ }^{130}$ Finally, in 1959, the Colonial Development Corporation launched a pilot programme similar to the Nigerian one, cooperating with the local government for the development of oil palm smallholdings. ${ }^{131}$ This collaboration was to favour increasing interaction between the foreign estate companies and FELDA.

The growing appeal of palm oil also triggered increased interest in the crop among leading research institutions, such as the Royal Botanic Gardens at Kew, and the Tropical Production

125 BC, TBB/1198, Correspondence with Malayan Estates, 1953.

126 CONGOPALM, 'Research on production and storage of palm oil: work carried out under the auspices of IRSIA, 1952-1955' (the Mongana report), 2 vols, Brussels, 1955 (mimeoed translation circulated in the 1980s by the Palm Growers' Council, Kuala Lumpur); Martin, UP saga, p. 187.

127 Fieldhouse, Merchant capital, p. 216.

128 Nicholas J. White, British business in post-colonial Malaysia, 1957-70, New York: Routledge, 2004.

129 LMA, CLC/B/112/MS37394/004, Nickalls' Papers, notes on post-war rehabilitation, 1958.

130 Rodolphe De Koninck, 'La paysannerie comme fer de lance territorial de l'état: le cas de la Malaysia', Cahiers des sciences humaines, 22, 3-4, 1986, pp. 355-70; Niels Fold, 'Oiling the palms: restructuring of settlement schemes in Malaysia and the new international trade regulations', World Development, 28, 3, 2000, pp. 4745.

131 TNA, DO/35/9993, 'Kulai oil palm estates, 1957-1960’. 
Institute (TPI) in London, through knowledge exchange between the two cluster locations and the creation of a global forum for palm oil experts. ${ }^{132}$ In the late 1950 s the TPI established a special unit, the Oil Palm Subcommittee, carrying out comparative research on Nigerian and Malaysian estates; ${ }^{133}$ in 1964 and 1965 it hosted the international Palm Oil Conference in London; ${ }^{134}$ and from 1966 it sponsored the Oil Palm News, a specialized publication intended to compile all updates on the crop and make them available to the international community of practice.

Furthermore, the increasing competitiveness of palm oil against other vegetable oils pushed cluster companies to cooperate towards improving its quality. As reported in the minutes of the special committee of the Unilever Plantation Executive in 1958:

owing to the length of time taken in plantation development for theories to be tested and knowledge to be gained, it could only be to the advantage of all concerned for a close relationship to be fostered and the results of research to be made mutually available. He [Mr. de Blank] suggested that it might be worthwhile to have some central direction for research programmes into oil palm development. Mr. Martin said that he had had some such thought in mind for some time, and it might be possible for the members of Rubber Research Institute to extend their activities to include oil palms. ${ }^{135}$

Initially, experts from Unilever had worked with Guthrie's researchers on pollination techniques, importing the rare Pisifera pollen from Africa to produce Teneras, while depending on the agency house for brokering services, and research on fertilizers. ${ }^{136}$ As the $1960 \mathrm{~s}$ approached, keen to expand its acreage in Asia, Unilever hired an increasing number of engineers with experience of Africa to carry out multiple collaborative projects. It also started negotiating with the Malaysian government the terms of its collaboration with FELDA, for the development of oil palm smallholdings.

At the same time, Unilever's representatives were exchanging information with Dunlop, H\&C, and the Rubber Research Institute. ${ }^{137}$ In 1962, the Plantation Executive instigated the formation of the Oil Palm Genetic Consortium, a joint initiative funded together with Guthrie, H\&C, and Dunlop to improve the Malaysian planting material. In 1963, the Consortium created the Oil Palm Genetic Laboratory. ${ }^{138}$ The project was under the direction of the geneticist J. J. Hardon, who reached Malaysia in 1964 after an extensive tour of Unilever's African operations. ${ }^{139}$ In 1963 the various findings were supplemented by the Belgian scientist A. Wolversperges' article in The Planter on the application of expeller presses to the process of palm oil extraction. ${ }^{140}$ This led to the diffusion of the new technology across all Asian estates during the 1960s. ${ }^{141}$

132

133

134

135

136

137

138

139

140

141

TNA, AY/4/2972, Oil palm news minutes, 1969. The TPI was established in 1955, changing the name and premises of the Colonial Products Laboratory in London: see Nature Publishing, 180, 4599, 1957.

TNA, AY/4/2570, 'Notes on commercial aspect of palm oil', 1959.

TNA, AY/4/2972, Oil palm news minutes, 1966-70.

UL, UNI/BD/SC/1/460, Minutes of the Special Committee with the Plantation Executive, 1958, p. 5.

UL, UNI/BD/SC/1/460, Minutes of the Special Committee with the Plantation Executive, 1955, p. 4.

UL, UNI/BD/SC/1/460, Minutes of the Special Committee with the Plantation Executive, 1960, p. 3.

Tate, RGA history, pp. 584, 595.

UL, UNI/BD/SC/1/462, Minutes of the Special Committee with the Plantation Executive, 1964, p. 2.

A. Wolversperges, 'The extraction of palm oil by means of screw presses', The Planter, 39, 1-3, 1963, pp. 11-14, 68-71, 111-13; Berger and Martin, 'History of palm oil', p. 402; Martin, UP saga, p. 185.

Charles Wilson, Unilever 1945-1965: challenge and response in the post-war industrial revolution, London: Cassell, 1968, pp. 78-9. 
Unilever's engagement in Asia grew as political stability in Malaysia improved relative to African locations, where independence was generally accompanied by a rapid deterioration in local business conditions. In 1960, after very poor performance for several years, the estates in the former Gold Coast (Ghana) were substituted by a new acquisition in the Borneo province of Sabah. ${ }^{142}$ In the same year, the Congo venture started reporting losses, as independence was followed by instability and a civil conflict, until General Mobutu seized power through a military coup in 1965 , posing further challenges to economic activity. ${ }^{143}$

In Nigeria, major public investment in plantations during the transition to independence, in the early 1960s, failed to produce the expected increase in employment. ${ }^{144}$ Thus, palm oil never achieved the status of scalable entrepreneurial activity, nor the reputation. In fact, locals associated oil production with poor living conditions in villages, while the new generation expected their children to accomplish more than tapping banga (palm fruit). ${ }^{145}$ This was further aggravated by the eruption of the Biafran secession war in 1967, leading to an almost $80 \%$ drop in palm oil production. By that time, Malaysia had achieved global leadership in palm oil production and export. ${ }^{146}$

Despite the sudden African downturn, the shift of leadership from Africa to Asia occurred through a gradual migration of palm oil experts to Asia, and a changed influence of the institutions connecting the two clusters. The TPI in London is a good example of how knowledge formation progressively shifted towards Asia, often transitioning through the UK. In 1963, C. W. S. Hartley, the editor of Oil Palm News and a major authority in palm oil studies, returned as senior researcher at the Malayan Agricultural Department, where he had spent his early career in the 1930s, working with Rosenquist. ${ }^{147}$ During the war, he had moved to West Africa, and had been the director of the WAIOPR in Nigeria for around a decade. ${ }^{148}$

In 1959, the Oil Palm Subcommittee gathered together all the key oil palm researchers of the time: Dr J. A. Cornelius, W. D. Raymond from TPI, T. A. Russel from Kew Gardens, Dr P. B. H. Tinker from WAIOPR, and Martin and De Blank from Unilever. ${ }^{149}$ From 1966, the committee, now called the Oil Palm Bureau, featured the same members from Unilever and TPI, but also included Hartley and, on the insistence of Martin, one representative from the association of the major plantation companies in Southeast Asia, the RGA, as well as one scientist from the Malaysian cluster on a rotational basis. ${ }^{150}$ These same people, together with experts who had been employed for the long term in Asia, such as (now) H\&C's B. S. Gray and Chemara's R. A. Bull, are acknowledged in the preface of the first edition of Hartley's influential publication The oil palm, resembling a directory of the community of practice specializing in the crop. ${ }^{151}$

142 UL, UNI/BD/SC/1/461, Minutes of the Special Committee with the Plantation Executive, 1961.

143 Fieldhouse, Unilever overseas.

144 Usoro, Nigerian oil palm industry, pp. 128-9.

145 Ukegbu, 'Production', p. 431.

146 TNA, AY/4/2972, Oil palm news minutes, 1969; Harcharan S. Khera, The oil palm industry of Malaysia: an economic study, Kuala Lumpur: Penerbit University Malaya, 1976, pp. 183-5.

147 Martin, UP saga, pp. 146-7.

148 TNA, AY/4/2972, Oil palm news minutes, 1969.

149 TNA, AY/4/2979, Palm oil committee, 1959.

150 TNA, AY/4/2972, Oil palm news minutes, letter from D. L. Martin, 7 July 1966; TNA, AY/4/2972, Oil palm news minutes, 1969.

151 Hartley, Oil palm, preface. Gray had joined H\&C from Guthrie in 1953: see Martin, UP saga, p. 120. 
Hence, with the emergence of Malaysia as the leading palm oil producer, institutions such as the RGA and the ISP, traditionally associated with the Malaysian rubber cluster, readjusted their focus on the new crop, and contributed to advance the knowledge on the oil palm. In 1966, the RGA extended its focus to crops other than rubber, and in 1967 and 1968 the ISP hosted the Malaysian Palm Oil Conference in Kuala Lumpur. ${ }^{152}$ In 1968, the Malaysian prime minister announced the creation of the Malaysian Agricultural Research and Development Institute (MARDI) to integrate the work of the TPI with local research and to support FELDA's oil palm acreage extension. ${ }^{153}$ Through these measures, and by hiring engineers and scientists previously employed in West Africa, the Malaysian cluster companies were able to catalyse the process of knowledge generation from Africa to Southeast Asia, de facto sealing their dominance over the location of origin.

Whereas in Africa the public sector had struggled to disseminate research among local farmers, the Malaysian government played a crucial role in using the cluster and the experts within it to expand the smallholding sector and to foster local development. By the end of the 1960s, FELDA had facilitated the integration of smallholders into the cluster organization. ${ }^{154}$ By involving the private sector in designing a model for oil palm schemes, the government had buttressed the gradual transformation of FELDA into an agribusiness corporation in its own right. $^{155}$

Unlike in Africa, where Unilever had long lobbied for establishing large-scale monocrop estates, in Malaysia a whole organization, preceding the entrance of the multinational, was in place to absorb and refine any fresh piece of information into both estates and small holdings. Hence, cluster companies and institutions were able to exploit the cooperation with Unilever to apply the existing rubber infrastructure to the needs of the new oil palm crop. From the mid 1960s this cooperation accrued further significance for the old British plantation houses such as Guthrie and H\&C. Teaming up on research and smallholding schemes strengthened their position with respect to the government, as they started feeling the threat of acquisition from rising ethnic Chinese companies. ${ }^{156}$

As for the public sector, the Malaysian government proved more effective than its African counterparts. Instead of obstructing foreign investment in estate development, it concentrated on creating incentives for foreign incumbents to cooperate with FELDA, such as granting new land contingent upon private-sector participation in joint smallholding schemes. ${ }^{157}$ For example, H\&C's and Guthrie's palm oil experts, B. S. Gray and P. T. Gunton, sat as advisors on the agency's board. Similarly, several estate companies ran regular training courses for FELDA staff. ${ }^{158}$

152 BC, TBB/830(2), Correspondence with Grut, November 1964; Tate, RGA history, p. 582.

153 TNA, AY/4/2973, Kuala Lumpur oil palm conference, Keynote speech minutes POAB, 1970.

154 Bryan C. MacAndrews, 'Mobility and modernisation: the Federal Land Development Authority and its role in modernising the rural Malay', PhD thesis, Massachusetts Institute of Technology, 1977.

155 Tunku Shamsul Bahrin, FELDA: three decades of evolution, Kuala Lumpur: FELDA, 1988.

156 Shakila Yacob and Nicholas J. White, 'The "unfinished business" of Malaysia's decolonisation: the origins of the Guthrie “dawn raid”', Modern Asian Studies, 44, 5, 2010, pp. 919-60.

157 Giacomin, 'Negotiating cluster boundaries', pp. 76-98.

158 LMA, CLC/B/112/MS37394/004, Nickalls’ Papers, H\&C strategy, 1969, p. 3. 


\section{Conclusion}

In sum, Southeast Asia emerged as a major palm oil exporter after 1955 thanks to its stronger public-private cooperation and its ability to attract the community of experts working on palm oil. However, the African cluster managed to maintain its leadership for almost fifty years after the oil palm was first domesticated in Asia. Political conditions and social trends in the context of decolonization ultimately affected the competition between the two clusters.

While historiography on palm oil has focused primarily on the local industries of Africa and Asia, this analysis shows how the industry advanced through a constant interplay of collaboration and rivalry between the two major producing regions. Foreign multinationals and communities of experts mediated the process of knowledge transfer between the two cluster locations, in the context of colonialism. Figure 1 offers an overview of the described competitive positions of the two palm oil locations, based on their relative export account, during the period under study. The two clusters coexisted for more than fifty years, until Southeast Asia reached a dominant share of global exports from the mid 1960s onwards. In 2016, Malaysia and Indonesia accounted for more than $80 \%$ of global exports (see Figure 2).

In terms of Porter's definition, both Southeast Asia (specifically, the Malay Peninsula, Sumatra, and Borneo), and the African Palm Oil Belt qualified as clusters. They were both circumscribed regions, presenting soil and climatic features suitable for the cultivation of the oil palm; palm oil was a major source of revenue in both territories during the period; and both presented specialized institutions facilitating research and commercialization of the crop (see Table 1).

However, these two clusters differed in terms of organization of production and internal cohesion. In Africa, palm oil production was a common village activity, which had been adapted for export. In Southeast Asia the existing rubber system, based on estates and smallholders, was repurposed to grow oil palms, initially on estates under foreign ownership, and later including smallholders. In Africa, within each colony, different interest groups long remained suspicious of each other. For example, in Nigeria, colonial officials feared the quasimonopolistic position of UAC, and the potential social backlash from introducing foreignmanaged estates. Cooperation among different colonial jurisdictions (British and Belgian) remained limited. Conversely, ownership was more fragmented in Southeast Asia and colonial governments were more supportive of foreign involvement in agriculture, while still adopting a laissez-faire approach towards local rubber smallholders. The geography of maritime Southeast Asia, and the presence of a major service hub in Singapore, facilitated the cluster's regional cohesiveness. As a result, knowledge and information flowed freely between Malaya and the Dutch East Indies, creating a strong 'co-operative spirit'. ${ }^{159}$

In line with the scholarship on communities of experts, palm oil production became more efficient through linkages between scientists and professionals. These engineers, botanists, agronomists, and so forth created close networks with hybrid figures, such as government officials, entrepreneurs, and executives. They constituted a transnational community between British West Africa, the Belgian Congo, and Southeast Asia. Further, they shared information and practices, and transferred specialized knowledge scattered across the two clusters, via a series of recurrent and durable institutions, constituting the cluster's ecosystem, such as 
botanical gardens, public research stations, international conferences and exhibitions, and international magazines and journals (see Table 1).

After stressing the benefits of experts' cooperation across locations, the article has explored the less well researched theme of competitive outcomes, resulting from the presence of a transnational community of practice. Indeed, the same distant interactions that enabled knowledge exchange also produced increased rivalry between the two clusters. Competition unfolded through migration within the community of practice, as resources and talent gradually shifted from Africa to Southeast Asia in the post-war period. This article has illustrated that rising competition from the more extractive Southeast Asian cluster increased the pressures on African locations to adapt their institutions to the Asian model. Local farmers were under pressure to reorganize their production to abide by the rules of globalization, although the extent of change remained relatively small.

In the context of developing economies, individual and corporate decisions on where to locate depended on the depth of the network, the quality of the business environment, and relative political stability. The last proved particularly important during the whole period. In the case of palm oil, the Netherland Indies had emerged as the global palm oil leader in less than two decades prior to the Second World War, seriously threatening African producers. Yet, sudden military and political crises in Southeast Asia favoured renewed investment in Africa, despite its less efficient organization. Similarly, the difficulties experienced by African locations after independence must be factored in when evaluating the success of the Malaysian palm oil cluster during the 1960s.

Finally, looking at the development of palm oil across its two producing poles sheds light on the role of commodity clusters as constitutive elements in the expansion of global capitalism, and not only as ways to organize production more effectively at the local level. In the context of colonialism, clustering facilitated resource extraction by multinationals, limiting the need to invest in infrastructure and easing the mobilization of resources in case of political turmoil.

Valeria Giacomin was Newcomen Fellow for the year 2017-2018 at Harvard Business School. Her research focuses on business history in emerging markets and on the history of clusters, global cities, and global commodity chains. 